\title{
FAKTOR PENGHAMBAT \\ PELAKSANAAN PUTUSAN YANG MEMPUNYAI \\ KEKUATAN HUKUM TETAP
}

\author{
Arifullah
}

\begin{abstract}
Abstrak
Arifullah, Nomor induk mahasiswa 4089.0135/8910208566, Beberapa faktor yang Menghambat Pelaksanaan Putusan yang Mempunyai Kekuatan Hukum Tetap Pada Pengadilan Negeri Kelas I Makassar di bawah bimbingan oleh Bapak Nasrun Usman Abdullah, SH. dan Iwan Akil SH.

Bahwa Skripsi ini bertujuan untuk mengetahui lebih mendalam tentang Eksekusi Putusan Hukum Perdata yang Telah Berkekuatan Hukum Tetap Pada Pengadilan Negeri Kelas I Makassar, tentang bagaimana cara serta prosedur yang harus ditempuh oleh pemohon eksekusi,sebagaimana yang terjadi didalam masyarakat,terkadang petugas eksekusi tidak ada rasa prikemanusiaannya terhadap sitereksekusi,serta factor-faktor yang mempengaruhi eksekusi sehingga eksekusi gagal dilaksanakan atau tidak tuntas pelaksanaannya sesuai dengan diktum putusan hukum yang telah berkekuatan hukum tetap yang dimohonkan eksekusi oleh pihak yang dimenangkan.

Dari hasil penelitian menunjukkan bahwa Eksekusi Putusan Hukum Perdata yang Telah Berkekuatan Hukum Tetap Pada Pengadilan Negeri Kelas I Makassar, belum sesuai dengan ketentuan yang berlaku karena adanya faktor yang mempengaruhi antara lain, tentang adanya peninjauan kembali, perlawanan pihak ketiga, banyaknya massa yang tereksekusi dan kurangnya aparat pengamanan, serta tidak jelasnya batas objek yang tereksekusi. Ini mengakibatkan,biasanya pemohon eksekusi harus berulangkali bermohon disebabkan eksekusi tidak tuntas atau gagal, atau biasanya kurangnya kerjasama antara pengadilan dengan instansi terkait lainnya.
\end{abstract}

Kata Kunci : Faktor Berpengaruh, Pelaksanaan Putusan, Kekuatan Hukum Tetap. 


\section{PENDAHULUAN}

\section{Latar belakang masalah}

Badan peradilan Negara adalah badan yang berkompoten menyelesaikan sengketa-sengketa perdata diantara warga masyarakat (undang-undang dasar 1945 pasal 24). KeKetentuan ini diperjelas lagi oleh Undang-undang no 14 tahun 1970 pasal (2) yang berbunyi :

"Penyelenggaraan

kekuasaan

kehakiman yang tercantum dalam pasal 1 diserahkan kepada badan peradilan dan ditetapkan oleh Undang-undang dengan tugas pokok untuk menerima juga memeriksa dan mengadili serta menyelenggarakan /menyelesaikan setiap perkara yang diajukan kepadanya".

Untuk melibatkan badan peradilan dalam menyelesaikan setiap sengketa perkara perdata, maka pihak yang merasa dirugikan harus mengajukan tuntutan hak, kemudian hakim memeriksa, mengadili dan memutuskan perkara tersebut. Terselesaikannya suatu sengketa oleh pengadilan sepenuhnya diserahkan kepada pihak-pihak yang berperkara dengan pengertian ruang lingkup pemeriksaan tergantung kepada kehendak kedua belah pihak yang berperkara. Dapat terselesaikan dengan cepat. Sudikno Mertukusumo 1988 : 168, menjelaskan hal ini sebagai berikut :

"Hakim di dalam memeriksa perkara perdata bersikap aktif dalam arti kata luas pokok sengketa yang diajukan kepada hakim untuk diperiksa pada asasnya ditentukan oleh pihak yang berperkara dan bukan oleh hakim”.

Selain itu Undang-undang no 14 tahun 1970 pasal 5 ayat (2) menegaskan bahwa dalam perkara perdata pengadilan berkewajiban membantu para pencari keadilan dan berusaha sekeras-kerasnya mengatasi segala hambatan dan rintangan, untuk dapat mewujudkan peradilan yang sederhana cepat dan biaya ringan. Oleh sebab itu seluruh pejabat yang ada dipengadilan harus berperan serta dalam mewujudkan peradilan yang cepat dan biaya ringan.

Tugas hakim hanyalah terbatas lahirnya suatu putusan, sedangkan tindak lanjut dari putusan itu adalah tugas dari pegawai pengadilan sebagai pelaksanaan putusan tersebut. Maka tanpa keterlibatan para petugas pelakasanaan putusan, penyelesaian perkara perdata kemungkinan tidak dapat diselesaikan. Oleh sebab itu jika tugas dan wewenang dari para petugas pelaksanaan putusan tidak dilaksanakan secara seksama, teliti dan tepat waktu, maka tidak hanya dapat merugikan penggugat tapi terlebih lagi tergugat dan bahkan dapat juga merugikan pihak ketiga. Akibatnya timbul perlawanan/bantahan dari pihak yang merasa dirugikan oleh proses pemeriksaan perkara perdata tersebut. Bila kita melihat kehidupan ditengah-tengah masyarakat, dimana manusia lahir sampai hayatnya berada diantara manusia yang lain, yaitu hidup dalam pergaulan masyarakat hal ini secara tegas dinyatakan oleh seseorang ahli filsafat Yunani yang bernama "Aristoteles" dan mengemukakan bahwa manusia itu adalah Zoon Politicon, Artinya bahwa 
manusia itu sebagai mahluk pada dasarnya selalu ingin bergaul dan berkumpul dengan sesama manusia lainnya, jadi mahluk yang suka bermasyarakat. Dan oleh karena sifatnya yang suka bergaul satu sama lain, maka manusia disebut mahluk sosial. Bertolak dari ungkapan itu Soejono menyatakan manusia sebagai anggota masyarakat tentu akan dapat merasakan bahwa kehidupan yang terjadi dialam ini kian hari kian konplex dan kebutuhan semakin banyak.

Setiap manusia mempunyai kebutuhan sendiri-sendiri dan sering kali kebutuhan itu searah satu dengan yang lainnya, sehingga dengan kerja sama tujuan manusia untuk memenuhi keperluan itu akan lebih mudah dan lekas tercapai akan tetapi seringkali pula kepentingan itu berlainan bahkan ada juga yang bertentangan sehingga dapat menimbulkan pertikaian dan mengganggu keserasian hidup bersama dalam hal ini orang dari golongan yang kuat menindas dari golongan yang lemah untuk menekan kehendaknya.

Sehubungan dengan hal itu, maka untuk mencegah perbuatan main hakim sendiri (eingenrichting) terhadap pihak yang merasa haknya dilanggar, diadakan tuntutan hak yang bertujuan untuk memproleh perlindungan hak yang diberikan oleh pihak pengadilan. Ini dapat mencegah timbulnya kerugian bagi pihak yang haknya dilanggar. Peristiwa yang semacam itu tentu tidak dikehendaki oleh setiap anggota masyarakat umum pada kenyataan sering saja terjadi dan biasanya tidak diduga sebelumnya. Suatu putusan hakim yang tetap mempunyai kekuatan hukum tetap, dapat dilaksanakan secara sukarela oleh yang bersangkutan sehingga dengan demikian dianggap perkara itu dianggap telah selesai tanpa memerlukan bantuan dari pengadilan untuk melaksanakan putusan tersebut.

Namun seringkali terjadi, setelah hakim memutuskan suatu perkara maka pihak yang akan kalah akan naik banding dan biasanya sampai ketingkat Mahkamah Agung jika putusan banding dari pengadilan tingkat negeri masih belum diterimanya. Bahkan putusan Mahkamah Agung masih sering tidak diterimah dan dengan mengajukan upaya hukum luar biasa yang kalah dalam perkara perdata menyangkut masalah tanah masih bercokol. Hal ini dapat juga menimbulkan dalam melakukan pengosongan tempat, tanah untuk diberikan sepenuhnya kepada pihak yang menang dalam perkara perdata tersebut.

Kasus semacam ini kita jumpai dalam perkara perdata yang menyangkut masalah tanah, dimana semestinya 14 hari setelah putusan dikeluarkan, pihak yang kalah dengan kerelahan harus meninggalkan tempat/tanah yang ditempati atau yang dikuasai selama ini. Akan tetapi tak jarang pihak yang kalah masih saja menempati tanah tersebut, sehingga pihak pengadilan sering turun tangan bahkan bantuan juga pihak yang berwajib untuk melaksanakan eksekusi tersebut. Berdasarkan hal tersebut diatas, maka dalam hal ini penulis akan membahas sejauhmana faktor penghambat pelaksanaan putusan yang mempunyai kekuatan hukum tetap. Menuntut penulis membahas masalah ini adalah yang sangat penting, oleh jika hal ini dibiarkan terus menerus akan berdampah negatif bagi lembaga peradilan dimana masyarakat akan 
mengacukan putusan-putusan yang akan dibuat oleh pengadilan Negeri Ujung Pandang pada khususnya sehingga apa yang diidam-idamkan selama ini tidak akan terwujud yaitu peradilan cepat, sederhana dan biaya ringan serta terciptanya masyarakat adil dan makmur yang berdasarkan ketuhanan Yang Maha Esa akan sulit tercapai.

Dalam hubungan itulah atau berdasarkan alasan-alasan tersebut diatas, maka penulis tertarik untuk mencoba mengkaji lebih dalam mengangkat dan mengangkat masalah ini sebagai objek kajian dengan judul :

\section{"BEBERAPA FAKTOR YANG MENGHAMBAT \\ PELAKSANAAN PUTUSAN \\ YANG TELAH MEMPUNYAI \\ KEKUATAN HUKUM TETAP: (STUDI) KASUS PADA PENGADILAN NEGERI UJUNG PANDANG"}

\section{Metode Penelitian.}

Dalam membahas skripsi ini penulis menggunakan pendekatan :

a. Yuridis Formal : yaitu pendekatan yang dilakukan dengan mempelajari / atau menelaah aturan-aturan / perangkatperangkat hukum yang ada kaitannya dengan pembehasan masalah ini;

b. Sosiologis : yaitu, pendekatan yang mengamati langsung kenyataankenyataan yang ada di masyarakat;

c. Komperatif : Yaitu, pendekatan yang merupakan perpaduan dari kedua pendekatan tersebut diatas, untuk membandingkan antara ketentuan yang mengatur putusan yang mempunyai kekuatan hukum tetap dengan proses yang terjadi pada kenyataan sehari-hari dalam masyarakat.

Disamping menggunakan cara pendekatan tersebut diatas, penulis juga melakukan penelitian dalam rangka pengumpulan data dengan menggunakan tehnik penelitian :

a. Penelitian kepustakaan ( Library research) yaitu, mencari data-data serta mengumpulkan bahan-bahan dengan menelaah buku-buku kepustakaan, tulisan-tulisan ilmiah, peraturanperaturan Perundang-Undangan yang relevan dengan materi penulisan skripsi ini, sehingga dapat dijadikan landasan berpikir untuk memperkuat dalil atau fakta Ilmiah penulisan. Penelitian kepustakaan memberikan kerangka teori sebagai acuan dalam mengkaji masalah yang ditinjau. Disamping itu dalam penelitian dilakukan pengambilan data external dari pengadilan Negeri Ujung Pandang. Data yang diproleh dari penelitian ini dilekatkan dari sumber yang sifatnya adalah data sekunder.

b. Penelitian Lapangan (Field Research) Yaitu, mengumpulkan data dengan melakukan penelitian langsung ke pengadilan Negeri Ujung Pandang pada pihak-pihak yang dianggap mempunyai pengetahuan luas dalam Hukum Acara Perdata atau praktisi-praktisi hukum.

\section{TINJAUAN PUSTAKA \\ Pengertian Putusan}

Putusan pengadilan merupakan sesuatu yang sangat diinginkan oleh pihak- 
pihak yang berperkara untuk menyelesaikan perkara mereka dengan sebaik-baiknya. sebab dengan putusan pengadilan tersebut pihak-pihak yang berperkara mengharapkan adanya kepastian hukum dan keadilan dalam perkara yang mereka hadapi.

Untuk dapat memberikan putusan pengadilan yang sebenar-benarnya menciptakan kepastian hukum dan mencerminkan keadilan, hakim sebagai aparatur negara yang melaksanakan peradilan harus benar-benar mengetahui duduk perkara yang sebenarnya dan peraturan hukum yang mengaturnya yang akan diterapkan, baik peraturan yang tertulis dalam perundang-undangan maupun peraturan hukum yang tidak tertulis dalam hukum adat.Oleh karena itu dalam Undangundang pokok kekuasaan kehakiman No 48 Tahun 2009 pasal 27 ayat (1) dinyatakan, bahwa hakim sebagai penegak hukum dan keadilan wajib menggali, mengikuti dan memahami nilai-nilai hukum yang hidup dalam masyarakat. (menurut Ridwan Syahrani, 1988 : 83).

Sedangkan mereka yang terlibat dalam perkara senantiasa selalu menantikan dengan harap-harap cemas, apakah putusan tersebut dapat dimenangkan oleh pihak mereka atau pihak lawan, apalagi perkara tersebut telah sampai kepada pengadilan yang lebih tinggi dan dilakukan persidangan untuk beberapa kali, sehingga telah banyak memakan biaya.Jadi tujuan kedua belah pihak dalam hukum acara perdata ini adalah untuk mendapatkan putusan dari pengadilan, yang berupa permohonan gugatan ditolak atau diterima.

Adapun pengertian tentang putusan pengadilan hakim menurut Sudikno
Mertokusumo ( 1988 : 167), adalah sebagai berikut :

"Putusan hakim adalah suatu pernyataan yang oleh hakim, sebagai pejabat negara yang diberi wewenang untuk itu diucapkan dipersidangan dan bertujuan untuk mengahiri atau menyelesaikan sengketa atau suatu perkara antara pihak.

Sedangkan menurut Ridwan Syahrani (1988 : 83 ), adalah sebagai berikut :

"putusan pengadilan adalah pernyataan hakim yang diucapkan pada sidang pengadilan yang terbuka untuk umum, untuk menyelesaikan atau mengahiri perkara perdata".

Untuk mencegah adanya perbedaan antara bunyi putusan yang diucapkan dipersidangan dengan bunyi putusan yang tertulis, Mahkamah Agung dengan surat edaran dengan no.5/1959 tanggal 20 april 1959 dan no.1/1962 tanggal 7 maret 1962 telah mengintruksikan kepada para Hakim antara lain agar pada waktu putusan pengadilan tersebut diucapkan konsep putusan harus sudah disiapkan/selesai.Sekalipun maksud surat edaran tersebut adalah untuk mencegah hambatan dalam penyelesaian perkara, tetapi dapat pula dicegah pula adanya perbedaan putusan yang diucapkan dengan putusan yang tertulis, maka yang sah adalah putusan yang diucapkan (lahirnya putusan itu sejak diucapkan).Tetapi sulitnya disini ialah pembuktian bahwa yang diucapkan berbeda dengan yang tertulis. Oleh karena itu setiap berita acara sidang seyogyanya 
harus sudah selesai sehari sebelum sidang berikutnya atau paling lama satu minggu sesudah sidang dan setiap putusan yang akan dijatuhkan sudah harus ada konsepnya.

Jadi Putusan adalah sebagai suatu perbuatan Hakim sebagai penguasa atau pejabat negara.Tidak mustahil bahwa salah satu pihak akan dirugikan oleh putusan hakim karena putusannya tidak dapat disebabkan Hakim yang bersangkutan kurang teliti memeriksanya. Maka akan timbul pertanyaan apakah sekiranya negara dapat mempertanggung jawabkan, atas kerugian yang diderita oleh salah satu pihak karena putusan yang keliru.Pada umumnya negara dalam hal ini tidak dapat dipertanggung jawabkan, karena bagi setiap orang yang merasa dirugikan oleh suatu putusan yang tidak tepat dapat menggunakan upaya-upaya Hukum kecuali apabila asas-asas hukum acara dilanggar oleh hakim, barulah negara dapat dipertanggung jawabkan.

Akan tetapi putusan Hakim bukanlah satu-satunya bentuk untuk menyelesaikan perkara. Disamping putusan hakim masih ada penetapan Hakim, hal ini dapat dilihat sebagai berikut :

1. Contentieus yaitu, dalam suatu perkara terdapat dua pihak atau lebih yang saling bersengketa, oleh karena itu putusan diambil untuk memutusi suatu perselisihan atau sengketa (perkara). Dalam hal ini, penyelesaian perkara dalam peradilan Contentieus disebut putusan (vonnis).

2. Voluntair yaitu, dalam suatu peristiwa hanya terdapat satu pihak atau dalam hal pengadilan (Hakim) melakukan suatu tindakan yang tidak berdasarkan suatu pemeriksaan terdapat dua pihak yang saling bersengketa/berselisih, tetapi dalam rangka suatu permohonan (yuridiksi Voluntaair) misalnya pengangkatan wali atau pengangkatan anak yang berstatus WNI oleh seorang WNA.Dalam hal ini penyelesaian perkara dalam peradilan Voluntair disebut penetapan (Beschinkking).

Adapun tujuan utama dalam suatu proses dimuka pengadilan adalah untuk memproleh eksekusi yang berkekuatan hukum tetap, artinya suatu putusan atau keputusan Hakim yang tidak dapat diubah lagi. Maksudnya dengan putusan ini hubungan antara kedua belah pihak yang berperkara ditetapkan untuk selamalamanya, supaya apabila tidak ditaati secara sukarela, maka dapat dipaksakan atas bantuan alat-alat negara (kekuatan hukum).(Subekti, 1977 : 124).

Dalam kaitannya dengan pengertian putusan Subekti tersebut eksekusi yang berkekuatan hukum tetap, maka selain pendapat dari Subekti tersebut diatas, masih terdapat beberapa pendapat sarjana lain mengenai pengertian putusan eksekusi yang berkekuatan hukum tetap tersebut, antara lain :

a. Menurut Sudikno Mertokusumo (1988 : 173 ), dikatakan bahwa :

"Suatu putusan memproleh kekuatan hukum pasti (kracht van gwijsde) apabila tidak ada lagi upaya hukum biasa yaitu, perlawanan, banding dan kasasi. Dengan memproleh kekuatan atau hukumyang maka putusan itu tidak dapat lagi dirubah, sekalipun 
oleh pihak pengadilan yang lebih tinggi, kecuali dengan upaya hukum khusus yaitu, Request Civil dan perlawanan pihak ketiga.

b. Menurut K.Wantjik Saleh (1981 : 123), dikatakan bahwa :putusan yang telah mempunyai kekuatan hukum tetapadalah sebagai berikut :

a. Putusan Pengadilan Negeri yang tidak dapat dilawanatau tidak dapat diajukan banding lagi.

b. Putusan Pengadilan Tinggi yang tidak dapat diajukan lagi.

c. Putusan Mahkamah Agung dalam tingkat kasasi.

Dari batasan pengertian tentang putusan eksekusi yang berkekuatan hukum tetap, seperti yang telah diuraikan diatas maka dapat ditarik kesimpulan pengertian tersebut yaitu :

1. Tidak ada lagi upaya hukum biasa ( perlawanan, banding, dan kasasi ) dalam putusan eksekusi yang berkekuatan hukum tetap.

2. Putusan Eksekusi yang berkekuatan hukum tetap tidak dapat lagi diubah, kecuali dengan upaya hukum khusus ( perlawanan pihak ketiga).

Kekuatan yang mengikat ini adalah suatu kemestian yang praktis berhubungan dengan tujuan hukum Perdata, yaitu untuk menentukan bagaimana pada akhirnya hubungan hukum antara kedua belah pihak dan untuk menentukan hukum yang menguasai soal yang menjadi perkara itu. Apa yang pada suatu waktu telah diselesaikan oleh hakim, tidak boleh diajukan lagi kepada hakim ( "Lites finiri opertet") adalah perlakuan prinsip umum, bahkan apabila dengan suatu tindakan acara
( processuele handeling) telah tercapai maksud yang biasa diharapkan, maka ulangan dari tindakan itu tidak akan mempunyai akibat hukum dalam bahasa latin disebut "Ne bis in idem".

Kekuatan putusan Hakim yang pasti dapat digunakan secara positif, yaitu apabila penggugat mendasarkan tuntutannya atas putusan hakim yang pasti dapat juga digunakan secara negatif, yaitu apabila seorang yang tergugat menolak suatu tuntutan dengan alasan bahwa tuntutan itu telah lama diputus oleh hakim, dan putusan itu telah menjadi pasti. Penolakan demikian dalam bahasa Belanda disebut "Exeptie van gewijsde zaak". Exceptie ini berlaku menurut prinsif ne bis in idem sedangkan kekuatan hakim yang pasti digunakan secara positif sesuai dengan prinsip res yudikata pro veritate habetur, yaitu putusan hakim yaang pasti dengan sendirinya mempunyai kekuatan hukum yang mengikat.

Seperti yang telah diuraikan diatas bahwa putusan eksekusi hukum tetap/pasti mempunyai kekuatan. Adapun kekuatan dalam putusan hakim (pengadilan) yang telah berkekuatan hukum tetap itu ada tiga macam yaitu :

a. Kekuatan mengikat

Putusan yang berkekuatan hukum tetap dengan sendirinya mempunyai kekuatan hukum yang mengikat (Prisipres Yudikata pro veritate habetur).untuk dapat melaksanakan atau merealisir suatu hak secara paksa bahkan diperlukan suatu putusan pengadilan atau akte autentik yang menetapkan hak itu. Suatu pengadilan yang telah pasti dimaksudkan untuk menyelesaikan suatu persoalan atau 
sengketa dan menetapkan hak atau hukumnya. Kalau pihak yang bersangkutan menyerahkan atau mempercayakan sengketanya kepada pihak Pengadilan (hakim) untuk diperiksa atau diadili, maka hal ini mengandung arti bahwa pihak-pihak yang bersangkutan akan tunduk dan patuh pada putusan yang dijatuhkan.

Karena itu putusan yang dijatuhkan pengadilan haruslah dihormati oleh pihakpihak yang berperkara ( kedua belah pihak), dan salah satu pihak tidak boleh melakukan tindakan yang bertentangan dengan putusan yang dijatuhkan tersebut ( pasal 1917 BW). b. Kekuatan pembuktian

Putusan Hakim yang telah mempunyai berkekuatan hukum tetap yang tertuang dalam bentuk tertulis adalah merupakan bukti autentik yang dapat digunakan sebagai alat bukti ( bewijs evidence ) oleh pihak yang berperkara sepanjang mengenai peristiwa yang telah ditetapkan dalam putusan itu. Karena putusan hakim yang pasti itu pembentuk hukum in concreto maka peristiwa yang telah ditetapkan itu dianggap benar,sehingga memproleh kekuatan bukti sempurna (volledig bewijskrecht,complete powerful evidennce). Seberapa jauh kekuatan bukti itu adalah terserah kepada kebijakan hakim ( pertimbangan ) hakim, sehingga putusan itu terhadap pihak ketiga mempunnyai banyak arti sebagai sangkaan(Martiman Projohamidjojo, 1983 : 22 ).

c. Kekuatan eksekutorial (Kekuatan untuk dilaksanakan).

Suatu putusan yang tetap/pasti dimaksudkan untuk menyelesaikan suatu persoalan atau sengketa dan menetapkan hak atau hukumnya. Ini tidak berarti semata-mata hanya menetapkan hak atau hukumnya saja, melainkan juga realisasi atau pelaksanaannya (eksekusi) secara paksa. Kekuatan mengikat saja dari suatu putusan pengadilan yang tetap/pasti belumlah cukup dan tidak berarti apabila putusan tersebut tidak dapat direalisir atau dilaksanakan.

\section{Hubungan gugatan dengan putusan.}

Sifat penting dari hukum acara perdata adalah bahwa pada hakekatnya pemeriksaan perkara perdata dimulai, dilanjutkan dan dihentikan atas kemauan penggugat sebagai seorang perorangan, dan negara atau pemerintah tidak dapat campur tangan. Ini sesuai sifat dari hak-hak dan kewajiban-kewajiban dalam hukum perdata, yang pelaksanaannya pada umumnya tergantung dari kemauan yang berhak sendiri atas pelaksanaan itu.

Adapun yang dimaksud dengan gugatan itu sendiri adalah, suatu cara bagi seseorang untuk melakukan tuntutan terhadap haknya, yang mana orang tersebut merasa dirugikan hak perdatanya (merasa haknya dilanggar) oleh seseorang atau beberapa orang.Guna dari tuntutan ini adalah bertujuan untuk memproleh perlindungan hak yang diberikan oleh pengadilan untuk mencegah main hakim sendiri (eigenrichting).

\section{Syarat-syarat dan isi putusan.}

Surat gugatan yang dibuat oleh hakim ini, ditandatangani oleh hakim (dalam hal penggugat atau tergugat buta huruf). Dalam putusan Mahkamah Agung tanggal 15 maret 1972 no. 547 K/Sip/1972 dinyatakan, karena dalam HIR dan RBQ 
tidak ada ketentuan mengenai syarat-syarat tentang surat isi gugatan, maka orang bebas menyusun dan merumuskan surat gugatan tersebut asal cukup memberikan gambaran tentang kejadian material yang menjadi dasar tuntutan.

Bagi kepentingan pencari keadilan, dalam pasal $119 \mathrm{HIR} /$ pasal $143 \mathrm{RBq}$ ditentukan bahwa Ketua Pengadilan Negeri berwenang memberikan nasehat dan bantuan kepada pihak penggugat atau kuasanya dalam membuat dan mengajukan gugatannya. Dengan demikian dapat dicegah pengajuan gugatan yang tidak sempurna kurang jelas/kurang lengkap yang akan dinyatakan tidak diterimah.

Apabila penggugat mengajukan surat gugatan kepada Ketua Pengadilan Negeri, maka ada tiga yang harus diperhatikan sebagai syarat dalam suatu surat gugatan pasal 8 ayat (1) Rv, yaitu :

1. Identitas para pihak

Yaitu, keterangan lengkap dari pihak-pihak yang berperkara (Penggugat dan tergugat) seperti ; nama alamat pekerjaan, agama, umur, status kawin atau tidak.

2. Fundamentum Petendi (posita)

Yaitu, dasar dari gugatan, yang terdiri dari dua bagian yaitu uraian tentang kejadian-kejadian atau peristiwa (feitelijke gronden, factaual grouds) yang merupakan duduk penjelasan peristiwanya salam perkara tersebut dan uraian tentang hukumnya (rechtsgrondeh) yang merupakan uraian tentang adanya hak atau hubungan hukum yang menjadi dasar yuridis dari pada tuntutan.

\section{Petitum (tuntutan)}

Yaitu, apa yang domohonkan atau yang dituntut oleh penggugat supaya diputuskan oleh pengadialn (hakim) petitum ini akan mendapat jawabannya dalam dictum atau amar putusannya dipengadilan, oleh karena itu pengugat harus merumuskan petitum dengan tegas dan jelas. Petitum ini adalah merupakan bagian yang terpenting dari suatu gugatan, oleh karena disinilah letak hubungan gugatan dengan putusan yang merupakan bahan yang terpenting bagi hakim dalam mempertimbangkan keputusannya terhadap perkara,hal ini dapat kita lihat dalam pasal 178 HIR/pasal RBq, yang berbunyi :

Hakim didalam memeriksa perkara perdata bersifat pasif, dalam arti kata dalam ruang lingkup atau luas pokok sengketa yang diajukan pada hakim untuk diperiksa pada asasnya ditentukan oleh pihak yang berperkara dan bukan oleh hakim. Hakim hanya membantu para pencari keadilan dan berusaha mengatasi selalu hambatan dan rintangan untuk dapat mencapai peradilan (pasal 5 undang-undang no. 14/1970).Hal ini memperjelas hubungan antara gugatan dan putusan, seperti yang kita lihat juga dalam pasal 178 HIR dimana hakim dalam memberikan putusan harus ada hubungannya antara gugatan dengan putusan yang dituntut oleh pihak-pihak yang berperkara itu.

\section{Macam-macam putusan.}

Pasal 185 ayat (1) HIR/pasal 196

ayat (1) RBQ membedakan putusan pengadilan ada dua macam yaitu,putusan akhir dan putusan bukan akhir. Putusan 
akhir ini menurut sifat amarnya (diktumnya) terdiri dari tiga macam putusan, yaitu :

Putusan akhir adalah putusan yang mengahiri suatu sengketa atau perkara perdata, pada tingkat pemeriksaan/peradilan tertentu.

Putusan akhir ini menurut sifat amarnya (diktumnya) terdiri dari 3 macam putusan, yaitu :

1. Putusan condemnatoir yaitu putusan yang bersifat menghukum pihak yang dikalahkan untuk melakukan suatu prestasi yang dibebankan oleh hakim atau tidak melakukan suatu prestasi.

2. Putusan Declaratoir yaitu putusan yang menyatakan dalam keadaan yang sah menurut hukum atau dengan kata lain putusan yang isinya bersifat menerangkan atau menyatakan apa yang sah(atau bersifat menyatakan, menegaskan suatu keadaan hukum semata-mata.

3. Putusan Konstitutif yaitu putusan yang meniadakan suatu keadaan hukum atau menciptakan/menimbulkan suatu keadaan hukum yang baru. Misalnya, seorang suami istri memohon kepada pengadilan untuk memutuskan ikatan perkawinan, atau seseorang memohon kepada hakim untuk menjadi wali bagi seorang anak dibawah umur atau permohonan seseorang untuk dinyatakan pailit, atau permohonan untuk membatalkan sesuatu perjanjian oleh karena salah satu pihak tidak memenuhi kewajibannya ( pasal 1266,pasal 1267 BW ).

\section{PEMBAHASAN \\ Faktor-faktor apakah yang menghambat pelaksanaan eksekusi yang sudah berkekuatan hukum tetap.}

Salah satu harapan masyarakat pencari keadilan khususnya pihak yang menang dalam perkara perdata (penggugat)adalah eksekusi pengadilan yang berkekuatan hukum tetap seharusnya dapat berjalan dengan lancar sesuai dengan hukum acara perdata.

Banyak hal yang menjadi penentu kelancaran dan ketetapan dalam melaksanakan putusan yang telah mempunyai kekuatan hukum tetap, baik yang bersifat yuridis seperti perangkatperangkat perundang-undangan dan non yuridis seperti keahlian atau kecakapan para petugas eksekusi dalam menjalankan tugasnya. Namun dalam menjalankan putusan yang berkekuatan hukum tetap pasti ini sering mengalami hambatan yang mengakibatkan tertundanya eksekusi dan bahkan adakalanya eksekusi tidak dapat dilanjutkan untuk waktu yang lama.

Berdasarkan hal tersebut diatas dan dengan melihat kenyataan-kenyataan dalam masyarakat, maka penulis menemukan beberapa hambatan lain dalam melakukan suatu eksekusi yaitu :

a. Hambatan dari sosiologis ini eksekusi terhadap suatu obyek sengketa biasanya terhambat karena masyarakat (pihak tereksekusi) tidak mau menerima suatu putusan yang telah tetap, oleh karena misalnya masyarakat (pihak tereksekusi) terpengaruh oleh hasutan dari orang-orang yang tidak bertanggung jawab yang mengatakan dengan adanya putusan 
tersebut tidak adil atau hakim yang memeriksa putusan berat sebelah, dan sebagainya. Sehingga mengakibatkan pihak tereksekusi tidak mau menjalankan atau memenuhi isi putusan.

Hal ini yang menyebabkan sehingga dalam melakukan suatu eksekusi, petugas eksekusi sering mendapat perlawanan secara pisik yaitu berupa pelemparan, pemukulan dan lain-lain. Atau ancaman-ancaman yang dapat membahayakan keselamatannya dari pihak tereksekusi yang tidak menerima putusan pengadilan tersebut, sanak keluarganya bahkan dari masyarakat sekitar obyek sengketa yang akan dieksekusi. Ini terjadi karena kurangnya tingkat kesadaran masyarakat (terutama pihak yang berperkara), akibat pihak yang masyarakat tidak didukung oleh pengetahuan yang luas.

b. Hambatan dari sosiologis ini disebabkan karena kurang propesionalnya para petugas eksekusi dalam menjalankan suatuputusan oleh karena para petugas eksekusi tersebut kurang mendapatkan pelatihan tentang tugas-tugas yang harus dilaksanakannya sehingga mereka belum dapat memenuhi kriteria sebagai petugas eksekusi yang cakap dan ahli dalam bidangnya. Hal ini mengakibatkan dalam melakukan tugasnya sebagai petugas eksekusi sering mengalami kesulitan dalam menterjemahkan suatu surat penetapan apalagi jika kondisi dilapangan tidak ada kesesuaian dengan adanya penetapan, sehingga petugas eksekusi biasanya menyita barang yang semestinya tidak perlu disita aksekusi atau petugas eksekusi tidak dapat memberikan keterangan yang baik terhadap yang tereksekusi sehinga terjadi kesalahpahaman. Berdasarkan hal tersebut diatas biasa timbul bantahan dari pihak yang biasa dirugikan sehingga mengakibatkan eksekusi ditangguhkan pelaksanaannya.

c. Hambatan yang disebabkan karena adanya kecenderungandari pada tugas tereksekusi yang senantiasa meminta bantuan polisi dalam melaksanakan tugasnya, sehingga ada ketergantungan dalam pelaksanaan tugas dari petugas eksekusi tersebut. Akibatnya jika polisi tidak dapat melaksanakan tugasnya dan ini dapat mengakibatkan tertundanya eksekusi.

d. Hambatan yang disebabkan karena adanya pertimbangan yang mempunyai alasan yang kuat dari ketua pengadilan Negeri, misalnya karena obyek sengketa yang akan dieksekusi mempunyai fungsi sosial yang luas dan diperuntukkan bagi kepentingan umum sedangkan pemohon eksekusi tidak terlalu membutuhkan obyek sengketa, atau dalam hal jika pihak tereksekusi adalah orang yang tidak mampu sedangkan obyek sengketa yang akan dieksekusi tidak terlalu mendesak untuk digunakan pemohon eksekusi, maka berdasarkan nilai-nilai prikemanusiaan biasanya ketua pengadilan Negeri mengabulkan permohonan penundaan eksekusi atas alasan prikemanusiaan untuk sementara waktu dengan maksud memberikan kesempatan bagi pihak tereksekusi untuk mencari tempat tinggal yang baru.

Contoh :

Kasus adanya faktor penghambat eksekusi dari segi sosiologis yaitu :

Putusan Mahkamah Agung no. K/Pdt/1986. Tertanggal 25 Februari 1957.

Mengingat putusan yang berkekuatan hukum pasti ini penggugat telah 
mengajukan permohonan eksekusi kepada ketua pengadilan Negeri kelas 1 Makassar pada tanggal 27 juli 1987, Kemudian oleh Ketua Pengadilan Negeri kelas 1 Makassar para tergugat telah dipanggil untuk diperingatkan pada tanggal 10 oktober 1987 dan pada tanggal 26 nopember 1987 agar memenuhi isi putusan dalam tempo 9 hari.

\section{PENUTUP}

\section{Kesimpulan}

1. Eksekusi adalah merupakan putusan terhadap pengadilan yang berkekuatan hukum tetap, dimana pada dasarnya, PasalPasal dalam HIR/RBq seharusnya berjalan dengan secara efektip dan lancar, namun didalam praktek sering kali terjadi mengalami hambatan atau menemui kesulitan dalam rangka pelaksanaan disuatu lapangan.

2. Dimana pada dasarnya bahwa tidak semua putusan hakim yang berkekutan hukum tetap dapat berjalan sesuai dengan apa yang diharapkan oleh pihak yang menang perkara (pihak yang berkepentingan), akan tetapi sering pula eksekusi suatu putusan yang berkekuatan pasti dapat banyak mendapat hambatanhambatan baik dari segi yuridis, sosiologis maupun dari segi ekonomis, sehingga kadangkala eksekusi tersebut menjadi tertunda.

$\begin{array}{rrlr} & \text { Adapun } & \text { hambatan } & \text { eksekusi } \\ \text { tersebut } & \text { yaitu } & \text { dikarenakan } & \text { adanya }\end{array}$ perlawanan dari pihak ketiga, hambatan lain karena adanya peninjauan kembali, hambatan karena tidak jelasnya batas-batas dari objek suatu sengketa yang akan dieksekusi, hambatan Karen adanya perlawanan pisik dari pihak tereksekusi terhadap petugas eksekusi, hambatan karena tidak adanya biaya untuk melakukan eksekusi serta hambatan Karen a adanya pertimbangan hakim disebabkan karena alasan prikemanusiaan.

3. Dari hasil penelitian penulis, mengetahui bahwa sekian banyak hambatan dalam eksekusi, maka hambatan yang paling dominan terjadi adalah hambatan yang berupa perlawanan fisik dari tereksekusi terhadap petugas eksekusi. Hal ini menyebabkan karena pada dasarnya pihak tereksekusi tidak mau menyerahkan objek sengketa. Hal ini merupakan hasil wawancara yang terakhir dengan bapak Mega Rumpang di pengadilan Negeri Kelas 1 Ujung Pandang.

\section{SARAN-SARAN}

1. Kiranya perluskali Mahkamah Agung serta instansi terkait, memikirkan untuk membuat sesuatu peraturan tersendiri mengenai aturan yang lebih jelas dan tegas tentang pelaksanaan putusan Hakim yang berkekuatan hukum tetap, agar pada pelaksanaan putusan Hakim yang berkekuatan hukum pasti dapat berjalan secara efektif dan lancar, sehingga tercapai peradilan yang cepat dan biaya ringan.

2. Hendaknya perlu sekali diberikan pelatihan-pelatihan dan penataran bagi petugas eksekusi untuk memberikan dedikasi dan keterampilan sehingga profesionalisme dalam menjalankan tugasnya, sehingga dalam menjalankan eksekusi tidak mengalami kesalahan atau kekeliruan. Sedangkan bagi masyarakat perlu lebih banyak diberikan penyuluhanpenyuluhan hukum secara periodik, 
sehingga dapat mengetahui fungsi dan Riduan Syahrani, Hukum Acara Perdata wewenang pengadilan.

b. Hendaknyalah petugas eksekusi sebelum Dilingkungan Peradilan Umum, pustaka Kartini, Jakarta 1988.

melaksanakan tugasnya,haruslah terlebih dahulu melakukan pemeriksaan setempat terhadap objek sengketa yang akan dieksekusi, agar nantinya didalam melaksanakan eksekusi tidak ada lagi hambatan.

c. Seharusnya pemerintah bersama DPR untuk membuat suatu peraturan khusus bagi tidak mampu membayar biaya eksekusi, sehingga dapat dihindari adanya putusan yang tidak dapat terlaksana dengan baik.

\section{DAFTAR PUSTAKA}

Muh.Abdul Kadir. Hukum Acara Perdata Indonesia, Cetakan kelima, PT. Citra Aditya Bakti, Bandung 1992.

Annim, Ketentua Pokok Kekuasaan Hakim dan Mahkamah Agung, pustaka tinta mas, Surabaya.

C.S.T.Cansil, Pengantar Ilmu Hukum dan Pengantar Tata Hukum Indonesia, Balai Pustaka, Jakarta,1982.

Djasuli Bachar, 1995, Eksekusi Putusan Perkara Perdata Segi Hukum dan Penegakan Hukum oleh Hakim, Penerbit Akademika Pressindo, Jakarta.

O.Bidara dan Martin P. Bidara, Hukum Acara Perdata,cetakan kedua, PT Pradya paramita, jakarta 1987.

Retnowulan Sutantio dan Iskandar Oeripkartawinata,1996. Hukum Acara Perdata dalam Teori dan Praktek. Bandung, Alumni.

Perdata. Jakarta, Fajar Agung.

Sudikno Mertokusumo, Hukum Acara Perdata Indonesia,edisi ketiga,cetakan pertama, liberty Yokyakarta tahun 1988.

Supomo, Hukum Acara Perdata Pengadilan Negeri, cetakan ke delapan, PT Pradya Paramita, Jakarta 1984.

Subekti,Hukum Acara Perdata,cetakan ketiga,bina cipta, Bandung1989.

Van Apeldorn, 1983. Pengantar Ilmu Hukum. Jakarta. Pradnya Paramita. Wantjik Saleh, K., 1985. Hak Anda Atas Tanah. Jakarta, Ghalia Indonesia 
